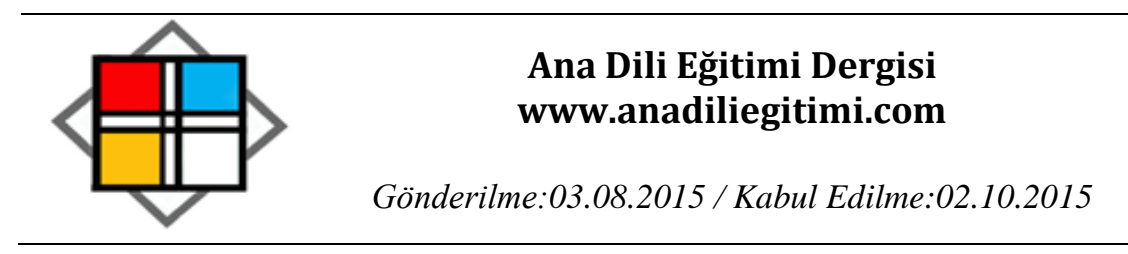

\title{
Türkçe Öğretiminde Drama
}

\author{
Mehmet KURUDAYIOĞLU* \\ Arzu ÖZDEM ${ }^{* *}$
}

\begin{abstract}
Öz
Türkçe dersinde drama yöntem ve tekniklerinin kullanıldığı etkinlikler ile: çocuklar metinleri daha iyi anlayabilme; aldıkları çeşitli roller sayesinde empati kurabilme; sağlıklı ve etkili iletişim kurabilme; duygu, düşünce ve hayallerini yaratıcı bir şekilde sözlü ve yazılı olarak dile getirebilme; eleştirel ve empatik dinleyebilme; dinlediklerini ve okuduklarını analiz ederek özetleyebilme; izlediklerini eleştirebilme, olaylar arasında ilişki kurabilme, sesini ve beden dilini etkili kullanabilme gibi yeterlikler kazanacaklardır.

Bu çalışma iki bölümden oluşmaktadır: ilk bölümde dramanın tanımı, özellikleri, Türkçe dil becerilerinin öğretimindeki önemi üzerinde durulmuş, ikinci bölümde ise Türkçe derslerinde dinleme, konuşma, okuma ve yazma becerilerinin geliştirilmesinde kullanılabilecek etkinlik örnekleri verilmiştir.
\end{abstract}

Anahtar Sözcükler: Türkçe, Türkçe öğretimi, dil becerileri, drama

\section{Drama in Teaching Turkish}

\begin{abstract}
In Turkish course through the drama methods and techniques, students would acquire competence such as, understanding texts, building up empathy, and healthy and effective communication, expressing feelings, thoughts and dreams in oral and written language creatively. Listening to the others critically and empathetically, analyzing and summarizing texts, criticizing what is watched, relating events, using voice and body language effectively are also important outcomes of teaching Turkish.

This study is consisted of two sections: In the first section, the definition and elements of drama, the importance of drama in teaching Turkish language skills are studied. In the second section, sample activities are suggested concerning developing listening, speaking, reading and writing skills.
\end{abstract}

Keywords: Turkish, Turkish language teaching, language skills, drama

"Doç. Dr., Abant İzzet Baysal Üniversitesi, Eğitim Fakültesi, Türkçe Eğitimi Bölümü, Bolu. E-posta: mkurudayi@hotmail.com.

** Türkçe Öğretmeni, Milli Eğitim Bakanlığı, Balıkesir. E-posta: turkceciozdem@hotmail.com. 


\section{Giriş}

Türkçe Dersi Öğretim Programı, yapılandırııı yaklaşım, öğrenci merkezli öğretim ve çoklu zekâ kuramı temel alınarak hazırlanmış ve 2006 yılında uygulamaya konulmuştur. Öğrencilerin gelişim özellikleri dikkate alınarak hazırlanan bu programda Türkçe dersinin bir bilgi dersi değil bir beceri dersi olduğu vurgulanmaktadır. Öğretmenin rehber olarak kurgulandığı yeni yaklaşımda dil becerilerini edinmiş, etkili iletişim kuran, çalışmalara katılan, ses ve bedenini etkili kullanan, kendine güvenen öğrenci profili ile karşılaşmaktayız. Bu özellikte öğrencilerin yetişebilmesi için başvurulacak en önemli yöntemlerden biri de "drama" dır.

Sözcük olarak Yunanca "dran"dan türetilmiş olup Eski Yunan'da "yaşamak" anlamına gelen drama, Türkçe Sözlükte "Dram”, dram ise "1. Sahnede oynanmak için yazılmış oyun. 2. Acıklı, üzüntülü olayları, bazen güldürücü yönlerini de katarak konu alan sahne oyunu veya televizyon filmi." (TDK, 2005: 572) olarak tanımlanmaktadır.

Drama, bir eylemin, bir olayın, bir duygunun, çeşitli rollerin, bir kavramın ya da öykünün, hatta şiirin, canlı ya da cansız varlıkların, sözel ve sözsüz, kendiliğinden davranışlarla, taklit yoluyla temsili olarak ifade edilmesi, canlandırımasıdır (Önder, 2007: 37). Başka bir tanımla drama, insanın insanla giriştiği her tür dolaysız, doğrudan ilişki, etki tepki alışverişi, arada oluşan en az düzeyde bir etkileşim bile bir dramatik an ya da dramatik bir durumdur (San, 1990: 573). Kısaca drama, hareket, konuşma, taklit gibi ögelerden yararlanarak doğa ve toplum olaylarının hayali bir ortam içinde canlandırılmasıdır.

Yukarıda verilen tanımlarda dikkatimizi canlandırmaya yapılan vurgu çekmektedir. Canlandırmayı yapabilmeleri için kendine güvenen, üreten, yaratan, sorun çözen öğrenci gerekir. Bu da drama ile gerçekleştirilebilir. Drama ile öğrenci, hayal ettiklerini, başından geçen olayları, taklit yoluyla anlatma imkânı bulur. Aynı zamanda öğrenciler, drama etkinlikleri aracılığıyla hem kendilerini hem de başkalarını tanıma fırsatı bulacaklardır.

Yaratıcı drama, çocukların hayal gücünün, yaratıcııı̆ının gelişmesini; kendisi hakkında beceri elde etmesini; duygularını ayırt etmesini; kelimeleri doğru ve yerinde kullanmasını; sıkılganlık duygusunu yenmesini; kolay öğrenmesini; çevresindekilerle etkin iletişimde bulunmasını; karar alıp uygulamasını sağlar (Dirim, 1998: 36-37). Drama etkinlikleri belirli aşamalarda gerçekleştirilir. Bu aşamalar hazırlık-ısınma, canlandırma ve değerlendirmedir.

Isınma aşamasında müzik ya da ritim eşliğinde koşma, yürüme, zıplama, ritim tutma gibi çalışmalar yapılabilir. Bu aşamada amaç, çocukların kendilerini ifade etmeye hazır hale gelmesini, iletişim kurmasını ve birbirleriyle kaynaşmalarını sağlamaktır.

Canlandırma aşamasında çalışma grubunun özelliklerine göre seçilen etkinlik gerçekleştirilir. Bu aşamada lider, oyunlarda aşırılığa kaçmamaya ve katılımcıları gereğinden fazla yormamaya özen göstermelidir. 


\section{Türkçe Öğretiminde Drama}

Değerlendirme aşamasında ise drama etkinliği süresince öğrencilere neler hissettikleri sorularak öğrencilerin kendi davranışları hakkında bilinçlenmeleri ve diğerlerinin davranışları üzerinde düşünerek empati geliştirmeleri sağlanır.

Drama etkinlikleri aşamalarının gerçekleşmesi için bir de bu süreci oluşturan diğer öğelerden bahsetmek gerekiyor. Drama etkinliği için katılımcılara, belirli bir mekâna, belirli bir içeriğe ve bu sürecin devamlılığını sağlayan bir drama liderine gerek vardır.

Drama etkinliği için önemli bir öge olan drama lideri/ öğretmeni, hedefleri belirleyen, bunun için kullanacağı strateji, yöntem ve teknikleri seçen, bu süreçte yararlanacağı araç, gereçleri hazırlayan ve sürecin nasıl değerlendirileceğine karar veren kişidir. Lider/öğretmen, iyi bir gözlemci olmalıdır. Demokratik, insanlara değer veren; öğrencilere güven veren; iletişime açık olan; sorumluluk sahibi ve karar verme yetisine sahip biri olmalıdır.

Drama çalışmalarında dikkat edilmesi gereken bazı kurallar ise şöyle sıralanabilir (MEB, 2005):

- Drama etkinliklerini uygulamak için önce uygun bir ortam oluşturulmalıdır.

- $\quad$ Özellikle rahatlama ve dikkat sağlama çalışmaları sırasında öğrencilerin birbirlerine dokunmayacakları bir alanın seçilmesi gerekir. Seçilen yer, koşulları uygun, rahat bir ortam olmalıdır.

- $\quad$ Öğrencilerin gelişim düzeylerinin dikkate alınması gerekir.

- Herhangi bir etkinliğe dikkatini yoğunlaştırması, ilgi göstermesi ve gerekli hareketleri yapabilmesi için istekli ve gönüllü olmaları önemlidir.

- Gerekli işbirliği ve ortam yaratmak için acele edilmemelidir. Bunun için dramaya gerekli süre ayrılmalıdır.

- $\quad$ Etkinlik seçiminde öğrencilerin görüşleri dikkate alınmalıdır. Öğrenciler kendi seçtikleri etkinliklere daha iyi yoğunlaşır ve zevk alırlar.

- Her drama etkinliğinden sonra etkinlik hakkında değerlendirmeler yapılmalıdır.

\section{Temel Dil Becerilerinin Kazandırılmasında Dramanın Önemi}

Dil, düşünce, duygu ve isteklerin, bir toplumda ses ve anlam yönünden ortak olan öğeler ve kurallardan yararlanılarak başkalarına aktarıımasını sağlayan, çok yönlü, çok gelişmiş bir dizge (Aksan, 2007: 55); insanların meramlarını anlatmak için kullandıkları bir sesli işaretler sistemidir (Banguoğlu, 1990: 9). Dil, duygu ve düşüncelerimizin karşı tarafa aktarılmasında bir araçtır. Bireyin iletişim kurması, intiyaçlarını giderebilmesi, isteklerini, sıkıntılarını, mutluluklarını aktarabilmesi için başvurduğu en önemli iletişim unsurudur.

Bütün ilişkilerimizi, iletişimimizi sağlayan, kültürümüzün aktarıcısı ve koruyucusu olan dil öğretimi tesadüflere bırakılamaz. Bunun için belli bir disiplin altında verilmelidir. Okullarımızda Türkçe öğretimi Türkçe Dersi Öğretim Programı́nın (MEB, 2006) temel felsefesini oluşturan yapılandırıcı 
yaklaşıma göre gerçekleşmektedir. Yapılandırmacı yaklaşımda öğretim öğrenci merkezlidir ve öğrencilerin yeni öğrendikleri, sahip oldukları eski bilgilerin üzerine inşa edilmektedir. Öğretim öğrencilerin yapmış oldukları etkinlikler vasıtasıyla olmaktadır.

Dil becerileri anlama ve anlatma olmak üzere önce iki başlık altında ele alınmaktadır. Dinleme ve okuma anlama becerilerini, konuşma ve yazma da anlatma becerilerini oluşturmaktadır. Türkçe öğretiminin temel amacı okuduğunu ve dinlediğini doğru anlayabilen ve sahip olduğu duygu ve düşünceleri konuşarak ve yazarak doğru anlatabilen bireyler yetiştirmektir.

Dil becerilerinin temelinde dili doğru kullanabilme, konuşabilme, okuduğunu anlama, okuduklarını ifade edebilme gibi birçok amaç vardır. Bunun için duygu ve düşüncelerin iyi ifade edilmesi gerekmektedir. Dil becerilerinde aktif, sosyal rolleri üstlenen, iletişimde başarılı çocukları yetiştirmeyi dramayla sağlarız. Türkçe dersinde uygulanacak drama etkinlikleriyle çocuklar metinleri daha iyi anlar, onları dramatize ederek eğlenir, aldıkları çeşitli rollerle empati kurar ve iletişim kurmada başarılı olurlar. Ayrıca öğrenciler, konuşmalarında seslerini kontrol ederek isteklerini net bir şekilde dile getirirler. Etkinliklerde dinlediklerini/izlediklerini analiz eder, eleştirir ve özetlerler.

Drama, öğrencinin yaparak, yaşayarak, algılayarak, kavrayarak ve aktif bir şekilde öğrenmesini sağlamaktadır. Drama, tiyatro tekniklerinden yararlanarak bir yaşamı, bir davranışı ve tümceyi oyunlar ve doğaçlamalar geliştirerek canlandırmaktır. Türkçe eğitiminde özellikle temel dil becerilerinin kazanılmasında drama aktif rol oynamaktadır. Dinleme konuşma, okuma, yazma becerilerini geliştirmek için drama etkinliği en iyi ortamdır. Bu yöntemin bir ucunun hayata dayanması, etkili öğrenmeye fırsat vermesi, soyuttan somuta kolay bir geçiş ortamı yaratması bir ifade ve beceri dersi olan Türkçe dersinde kullanılan alternatif bir yöntem olmasını sağlamıştır. Öğrenciler tarafından en az katılımın olduğu, birçoğunun kendini sakladığı dil bilgisi derslerinde bile öğrenciyi aktif hale getirebilmek için drama en uygun yöntemdir (Kara, 2007: 97).

Drama yöntemi, bir duygu veya düşüncenin, hareket, mimik, jest ve sözle anlatılmasıdır. Bir başka deyişle, bir konu ya da durumun canlandırılması, yaşayarak yansıtılması, yaşantıya dönüştürülmesidir. Bu yöntem öğrencinin anlama ve anlatma yeteneklerini, kişiliğini daha çok geliştirir. Türkçe de her şeyden önce bir anlama ve anlatma dersi olduğuna göre, dramanın önemi kolayca anlaşılır (Karadağ ve Çalışkan, 2005: 94).

\section{Dinleme Eğitimi ve Drama}

Türkçe Sözlük'te (TDK, 2005) "İ̧̧itmek için kulak vermek" olarak belirtilen dinlemeyi Özbay (2006a: 44), kişinin tercihine bağlı olarak, seçerek ve isteyerek algıladığı sesler bütünü olarak tanımlamaktadır.

Türkçe öğretimin öncelikli hedefi öğrencilere öğretim programındaki becerileri kazandırmaktır. Bunlardan biri olan dinleme ve anlama sadece bu ders için değil her alan için gereklidir. Dinleme, günlük 


\section{Türkçe Öğretiminde Drama}

hayatta çokça başvurduğumuz bir beceridir. Önemli olan bu beceriyi ne kadar etkili yaptığımızdır çünkü dinlemek bir dikkat ve sabır işidir.

Dinleme/izleme becerisini geliştirmek için öğrencilerin karşılıklı etkileşim içinde olduğu öğrenci merkezli bir yönteme başvurulmalıdır ki onları dinleme işinde edilgenlikten kurtarabilelim.

Demirel'e (2002) göre, drama, etkili ve dikkatli dinleme, anlama yeteneğini geliştirir ve öğrencinin kendine güvenini artırır. Öğrenci merkezli olan drama teknikleri sayesinde öğrenci dinlediğini anlama davranışını "yaparak, yaşayarak, öğrenme stratejisi”ne uygun olarak kalıcı bir şekilde kazanmış olabilir. Soyut, karmaşık, anlaşılması zor birçok konu, canlandırma yolu ile öğrencide somut bir hale getirilebilir (Köklü, 2003: 101).

Öğretimde önemli olan öğrenciyi edilgen bir dinleyici durumundan kurtarabilmek, onu duyu organları ile harekete geçirebilmek, konuları canlandırarak yaşanır duruma getirebilmek olduğuna göre drama etkinlikleri, bu süreçte uygun bir seçenek olarak görülebilir. Böylelikle öğrenci öğrenme sürecinde etkin durumdadır, bizzat kendi yaptığıyla öğrenirken bir yandan da duyu organlarını harekete geçirmekte, olay ya da durumları yaşamaktadır (Üstündağ, 1988: 59; Köklü, 2003: 88).

Eğitim- öğretimde esas amaç öğrencilerin olabildiğince fazla duyu organını harekete geçirerek daha etkili bir öğrenme ortamı sağlamaktır. Bu manada dramatizasyon yöntemi öğrencilerin hem görme hem de dinleme duyularını harekete geçirmektedir. Canlandırmada rol alan öğrencilerin dışında kalan öğrenciler hem canlandırmayı izlemekte hem de dinlemektedir. Görsel unsurlarla desteklenmiş bir anlatımı ifade eden dramatizasyon öğrencilere etkili dinleme ortamı sağlamaktadır. Rol alan öğrenciler olayı/ durumu yaşayarak ve yaparak öğrenirken diğer öğrenciler izleyerek ve dinleyerek öğrenmektedirler (Özbay, 2006a: 144).

Dinleme becerisinin kazandırılmasında görme ve işitme çok önemli iki duyudur. Öğrencilerimize bir metni verip okuttuğumuzda hem okuma hem de dinleme becerisinden yararlanmış oluruz. Okunan metni dinleyen öğrenci, o metindeki kahramanları, yeri, zamanı, olayları zihninde canlandırır. Zihinlerinde canlandırdıkları olayları drama ile somutlaştırarak metni, çocukların kendi yaşantısının bir parçası haline getirmiş oluruz. Metnin somutlaştırılmasıyla metin daha ilgi çekici ve eğlenceli olacaktır.

Türkçe dersinde metinlerdeki olay ve durumlar, değişik kişiliklere bürünerek canlandırılabilir. Öğrenci, böylece kendisinde başkasını yaşama yoluyla yaşantı zenginliği elde edecektir. Ayrıca öğrenci salt dinlemekle kalmadığı bir öyküyü ya da şiiri canlandırarak daha iyi özümseyecektir (Köklü, 2003: 87).

Çocuklara dinlemenin önemini anlatırken başvuracağımı canlandırmalar, onları eğlendirecektir. Söz gelimi doğadaki sesleri dinleyip o sesi betimlemek, yeni imgeler oluşturup karşı tarafa aktarmak, bunun karşıdakiler tarafından dinlenilmesini istemek ve dinlenildiğini fark etmek öğrenciler açısından zevkli olacaktır. 


\section{Okuma Eğitimi ve Drama}

Okuma, bilişsel davranışlarla psikomotor becerilerin ortak çalışmasıyla, yazılı sembollerden anlam çıkarma etkinliğidir (Demirel, 2002: 77). Okuma, kelimeleri, cümleleri, noktalama işaretleriyle, bir yazıyı bir bütün olarak görme, algılama ve kavrama sürecidir (Ünalan, 2006: 62).

Okuma becerisini öğrencilere kazandırabilmek için onların dikkatini çekecek şeyler yapmalıyız. Bu beceriyi benimsemeleri için öğrenciler eğlenirken okumalı, okurken eğlenmelilerdir. Klasik okuma öğretimi ile öğrencilere bu beceriyi öğretmede başarılı olduğumuz söylenemez. Öğrenciler drama çalışmaları ile okudukları metinleri canlandırarak hem okumalarını hem konuşmalarını geliştirebilirler.

Okuma tiyatrosu alıştırmaları da drama kapsamına girer. Bu tür çalışmalarda amaç, öğrencilere metnin dilini, yapısını, metinde yer alan şahıs ve varlık kadrosunun özelliklerini sezdirmektir. Metin okunduktan sonra diyaloglarla tiyatro metnine dönüştürülür. Metnin içeriği ve iletisi değiştirilemez. Diyaloglar olaylardan, konuşma cümlelerinden hareketle oluşturulur. Betimleme bölümleri, olay kahramanının konuşma cümleleriyle verilir. Her öğrenci okuyacağı bölüme hazırlanır (Şimşek, 2007:400).

Okuma eğitiminde drama kullanarak çocukların, okunan metni tam olarak kavraması sağlanır. Öğretmen derste işlenecek parçayı örnek olarak okur ve daha sonra öğrencilerden aynı parçayı okumasını ister. Öğretmen metni okurken vurgu ve tonlamaya, jest ve mimiklerine dikkat eder. Öğrenciler çok iyi gözlemci oldukları için onlar da öğretmenleri gibi dikkat ederek okurlar (Karadağ ve Çalışkan, 2005: 96). Drama etkinlikleri ile öğrenciler okudukları metni daha iyi kavradıklarını, karakterleri ve olayları özümsediklerini, metni canlandırarak metindeki olayları somutlaştırıp kendi yaşantıları haline getirdiklerini göreceklerdir.

\section{Konuşma Eğitimi ve Drama}

Günlük hayatımızın hemen hemen bütününü kapsayan konuşma, Türkçe Sözlük'te “ 1 . Konuşmak işi. 2. Görüşme, danışma, müzakere. 3. Dinleyicilere bilim, sanat, edebiyat, vb. konularda bilgi vermek için yapılan söyleşi, konferans." (TDK, 2005: 1212) olarak tanımlanmaktadır. Kısaca konuşma, düşüncelerin, duyguların ve bilgilerin seslerden oluşan dil aracılığıyla aktarılmasıdır (Demirel, 2002: 90).

Dramada iletişim ve etkileşim söz konusu olduğu için anlatım gelişir. Oyunlardaki canlandırma bölümlerinde çocuk hem sesini, hem bedenini, hem yaratıcılığını, hem düşüncelerini, hem de kendini anlatma yetisini geliştirir (Yılmaz, 1999: 6).

Konuşma becerisinin etkin kullanımı sayesinde duygu, düşünce ve hayallerimizi karşımızdaki insanlara etkili bir şekilde aktarabiliriz. Bu amaç için de Türkçenin güzelliklerini ve inceliklerini yansıtan, kalıplaşmış ifadelerden uzak, etkili ve güzel cümleler kurmalıyız. Bunu yapabilmek için de kendimize 


\section{Türkçe Öğretiminde Drama}

güvenmeli; ses tonumuzu iyi ayarlayabilmeliyiz. Topluluk karşısında heyecanını, jest ve mimiklerini, sesini kontrol edip cesaretle konuşmak için başvurabileceğimiz en etkili yöntemlerden biri de dramadır.

Konuşma becerisi sadece sözcükleri doğru telaffuz etmek değildir. Bu şekilde yapılacak öğretim çocukları ezberciliğe; kalıplaşmış cümle kurmaya; kendini rahat ifade edememeye itecektir. Konuşma eğitimi, sadece bir öğretim şeklinde değil; oyun, uygulama ve eğitim şeklinde olmalıdır. Konuşma öğretilebilecek bir beceri değil, aksine uygulama ve eğitimle gelişen bir beceridir (Yalçın, 2002:144). Aynı şekilde, konuşma, sadece kelimeleri doğru söylemek, düzgün yapılı cümleler kurmak değildir. Bu becerinin içerisinde vurgu ve tonlamayı da kullanmak önemlidir. Çocukların seslerini kullanamama sebepleri içerisinde ezbercilik yatmaktadır. Oysa dramayla birlikte ezber ortadan kalkacağı için öğrenci konuşmasını etkili kullanma gayreti içerisine girecek sözcüklerin söyleyiş özelliklerinden vurgu ve tonlamaya dikkat edecektir (Kara, 2007: 98).

Türkçe öğretiminde üzerinde sıkça durulan empati kurabilme, iletişim kurma, karar verme, yaratıcı düşünme gibi becerileri öğrencilerimizde görebilmek için onların kendilerini rahatça ifade edebilecekleri ortamlar oluşturulmalıdır. Öğrenciler, duygu ve düşüncelerini çekinmeden aktarmalı; konuşmaları ile insanlar üzerinde etki bırakmalıdır.

Illköğretim çağındaki öğrencilerin en büyük problemlerinden biri de duygularını sözlü anlatıma rahatça aktaramamalarıdır. Öğrenci konuşurken çekingen davranmakta, duygularını ve isteklerini anlatmakta zorluk çekmektedir. Oysa sınıfta canlandırılan bir hikâyede ya da masalda özgürce kendini ifade etme şansı bulacaktır. Zamanla isteklerini ve duygularını karşısındakine rahatça anlatabilecek hatta empati kurma yoluna bile gidecektir. Başkaları da onu dinlediği için sözlü konuşma becerisi artacaktır. Çocuğun kendisi olarak değil de rolüne girdiği karakterin adına konuşması kendisini özgür hissetmesini sağlayacaktır. Bu eğlendirici yanı çocuğu sıkan ve dersten uzaklaştıran diğer yöntemlerden dramayı üstün kılar (Kara, 2007: 97).

Öğrenciler çoğu zaman konuşmaya karşı isteksizdirler. Yaratıcı drama bu probleme çözüm bulmanın en etkin yoludur. Öğrenciler arkadaşlarıyla, anne babalarıyla nasıl rahat konuşuyorlarsa, saygı çerçevesinde, öğretmenleriyle ve toplum karşısında da rahat konuşabilmelidir. Türkçe derslerinde verilen bir konu hakkında öğrencilerin tekrarlara düşmeden rahatça konuşmaları için dramadan yararlanılır. Öğrencinin sınıf içinde, o anda kendisine verilen bir konu üzerinde akıcı bir şekilde konuşması istenir. Bu tür etkinlikler ilk başta zor gelse de zamanla bunlara alışılır. Verilen uygun metinlerle öğrenciler karşııklı konuşturulur. Karşııklı konuşmalarda dikkat edilmesi gereken kurallar öğrenciye sezdirilir (Aytaş, 2008: 16).

Drama, çocuklara gördüklerini ya da hayal ettiklerini hareket, konuşma ve taklit yoluyla anlatma imkânı sağlar. Onlara başkalarının durum ve davranışlarını canlandırırken kendi duygu ve düşüncelerini de belirtme fırsatları verir. Drama etkinlikleri aracılığıyla çocuklar hem başkalarını hem 
de kendilerini daha iyi tanımaya başlarlar. Kelime hazinelerinin zenginleşmesinin yanında anlatım bakımından da gelişme gösterirler (Ünalan, 2006: 40).

Demirel (2002) ise dramayı biçimsel ve doğal drama adı altında iki başlığa ayıııp doğal dramanın amacının bireylere serbest konuşma alışkanlığı kazandırmak, onların duygu ve düşüncelerini kendi sözcükleriyle diledikleri gibi açıklama yapmalarına olanak sağlayıcı olduğunu belirtmiştir.

Öğrenciler, doğaçlama ve canlandırma etkinlikleri ile seslerini etkili kullanır, vurgu ve tonlamalara dikkat ederler. Bu etkinliklerle seslerini alçaltıp yükseltebilir; diksiyon ve boğumlama çalışmaları da yapabilirler.

Türkçe derslerinin çocuğun doğasına uygun olarak, kendini rahatça ifade edebileceği, grup etkileşiminde bulunabileceği öğrenme durumlarında yürütülmesi gerekmektedir. Çağdaş bir yöntem olan dramanın kullanımı ile çocukların temel dil becerilerini geliştirebilecekleri, kendilerini özgürce ifade edebilecekleri görülmektedir (Kara, 2007: 98).

Konuşma becerisinin geliştirilmesiyle öğrenciler, kendilerine güvenen bir tavırla topluluk karşısında doğru cümle kurabilirler. Bunun için de sınıf içerisinde uygun bir ortamın oluşturulması gerekir. Kendilerini rahat hissedebilecekleri bir diğer ortam ise grup çalışmalarıdır. Grup ile yapılan drama etkinlikleri öğrencinin insanlarla iletişim kurmasını, kendine güvenmesini, kendini rahat ifade etmesini sağlar. Deneyimlerini paylaşarak, farkıı bakış açılarını öğrenirler. Grupla etkileşim sonucunda öğrenci sosyalleşmiş olur. Bu çalışmalar sonucunda başkalarıyla rahat konuşan, sağlıklı iletişim kuran bireyler yetişir.

Konuşma becerisinin ediniminde yapılan drama etkinlikleri ile kendine güvenen; ses, jest ve mimiklerini rahatlıkla kullanan; hazırıklı ya da hazırlıksız konuşmalarda heyecanlarını kontrol edebilen; belli bir topluluğa hitap edebilen; fikirlerini akıcı bir şekilde dile getirebilen; kelime hazinesi gelişen bireyler yetiştirebiliriz.

\section{Yazma Eğitimi ve Drama}

Yazma, duygu, düşünce, istek ve olayların belli kurallara uygun olarak birtakım sembollerle anlatılmasıdır (Özbay, 2006b: 121). Yazma; iletişim kurmanın, duygu, düşünce ve tasarılarımızı, görüp yaşadıklarımızı anlatmanın bir yolu olup aynı zamanda düzenli düşünme alışkanlığı da kazandırır (Ünalan, 2006: 99).

Ilköğretimin ilk kademesinden itibaren duygu ve düşüncelerimizin bizden yazılması istenir. Ne var ki hepimiz kalemi alır ve boş kâğıda bir şeyler yazar, siler, tekrar yazarız. Bu işi yaparken de genellikle sıkıldığımızı belli edici sesler çıkartııı. Yazma işi tüm hayatımız boyunca sıkıcı ve zor olarak nitelendirilir. Oysaki yazma, öğrencinin kendini rahatlıkla ifade edebileceği bir beceri olmalıdır. Yazma becerisi ne kadar rahat ve eğlenceli ortamda yapılırsa öğrencinin de yazmaya karşı isteği o kadar artacaktır. Drama etkinlikleriyle yazma becerisini zevkli hale getirebileceğimiz bir ortam oluşturabiliriz. 
Yaratıcı drama yazılı anlatma becerisini de olumlu yönde geliştirir. Yapılan bir etkinliğin sonucunun değerlendirilmesi veya bu etkinlikle ilgili hazırlık planı yazılı olarak istenebilir. Bütün bunlar, öncelikle yazma becerisinin geliştirilmesinde rahatlatıcı, daha sonra da geliştirici bir etkiye neden olacaktır (Aytaş, 2008: 16).

Edebi türlerin yazımında da drama etkinliklerine başvurulabilir:

Öğretmen bir anahtar sözcük söyler ve bu sözcükle ilgili kompozisyon yazılmasını ister. Yaşanılan ya da yaşanması istenen bir olay, gazete haberi vb. konuları yazdırılarak çocukların yazma becerileri geliştirilir (Ünsal, 2005: 45).

Yaratıcı drama öykülerden pek çok biçimde yararlanabilir. Bunların bir bölümü var olan öyküler üzerinde çalışmaktır, bir bölümü de yeni öyküler yaratmak olabilir. Var olan öykülerin başlangıcını, ortasını ve sonunu değiştirmek, bilinen öyküleri bir araya getirip yeni öyküler yazmak bu çalışmalar arasında yer alabilir (Üstündağ, 2009: 64).

Verilen sözcüklerden hareketle şiir yazma etkinlikleri de dil gelişimine yönelik yaratıcı drama çalışmalarıdır. Öğretmen tahtaya sözcükleri yazar ve bu sözcüklerden hareketle birer dörtlük oluşturmalarını öğrencilerden ister (Şimşek, 2007: 405).

Öykü yazma çalışmalarında, ya bilinen bir metin yeniden kurgulanır ya da tespit edilen ögeler çevresinde bir öykü oluşturulur. Öğrencilere bir öykünün tip, yer, konu, düğüm (sorun) gibi ögeleri kura çekimiyle belirlenerek verilir. Öğrencilerden bu ögeleri kullanarak birer öykü yazmaları istenir (Şimşek, 2007: 402).

Yazma becerisini geliştirmek için öğrencilere bu zamana kadar uygulanmış olan, onları sıkan, zorlayan uygulamalardan vazgeçilip drama çalışmaları yaptırılmalıdır. Cümle ve kelime oyunları da yapılabilecek drama etkinlikleri arasındadır:

Dil çalışmaları kapsamında cümle kurma oyunları oynanır. Oyun yöneticisi, tahtaya herhangi bir kelime yazar. Öğrenciler bu kelimenin harfleriyle başlayan kelimelerle birer cümle kurarlar (Şimşek, 2007: 404).

Drama etkinlikleriyle öğrencilerimiz, önündeki boş kâğıda sıkılarak değil zevkle ve heyecanla eğileceklerdir. Kalemlerini istekle tutup duygu ve düşüncelerini rahatlıkla yazıya dökeceklerdir.

\section{Temel Dil Becerilerinin Geliştirilmesine Yönelik Drama Etkinlikleri}

Bu bölümde, Türkçe öğretmenlerinin, öğrencilerinin dil becerilerini geliştirmek için derslerinde kullanabilecekleri örnek drama etkinlikleri üzerinde durulmuştur. Drama etkinlikleri hazırlık- ısınma, canlandırma ve değerlendirme aşamalarından oluşmaktadır. Aşağıda verilen etkinliklerde hazırlık ısınma ve canlandırma aşamaları verilmiştir. Değerlendirme aşamasını, Türkçe öğretmeni, öğrenci seviyesine göre sınıf ortamında öğrencilerine yönlendireceği sorularla yapabileceğinden ayrıca 
değerlendirme aşaması verilmemiştir. Etkinlik örnekleri, Önder (2007), Üstündağ (2009), Aytaş (2008), Arıkan (2007), Baş (2002), Rooyackers (2009) ve Şimşek (2007) 'den derlenmiştir.

\section{ÖRNEK ETKINLIK - 1}

\section{Etkinliğin Adı: Metin Canlandırılması}

Etkinliğin Uygulanışı: Sınıf canlandırmaya uygun olarak düzenlenir. Canlandırma metni çoğaltııı canlandırmada görev alanlara dağıtılarak prova ve hazırlık için belli bir süre tanınır. Her bir öğrenciye canlandıracağı karakterler hakkında bilgi verilir. Daha sonra her öğrenci elindeki metinden, canlandıracağı karakterle ilgili bölümleri okur. Önce sessiz olarak okunan metin, daha sonra sesli olarak okunur. Bunun ardından oyun canlandırılır. Canlandırma yapıldıktan sonra öncelikle canlandırmada görev alan kişilerin oyun hakkındaki yorumları alınır. Daha sonra izleyenlerin oyundan nasıl bir sonuç çıkardığı öğrenilir.

\section{ÖRNEK ETKINLIK - 2}

\section{Etkinliğin adı: Bu Ne Sesi?}

Etkinliğin Uygulanışı: Öğrencilerden başlarını sıranın üzerine koyup gözlerini kapatmaları istenir. Öğrencilere bazı sesler duyacağı söylenilir. Sonra öğrencilerden bu seslerin hangi varlıkla ilintili olduğunu anlamaya çalışmaları istenilir.

Kullanılabilecek sesler şunlar olabilir:

- $\quad$ Yere kitap düşürme

- $\quad$ Kendinden emin bir insan yürüyüşü

- $\quad$ Bir yere yetişmeye çalışan aceleci bir insan yürüyüşü

- $\quad$ ip atlama sesi

- $\quad$ Öpme sesi

- $\quad$ Alkış

- $\quad$ Pencereyi açıp kapama

- $\quad$ Bir kitabın sayfalarını çevirme

- Tahtaya yazı yazarken tebeşirin çıkardığı ses

- $\quad$ Sandalyeyi bir yerden bir yere taşıma

Sesler, önce kuvvetli, rahatsız edecek biçimde sonra da hafifleterek verilir. Sonra sesleri dinleme anına dair sorular sorulur: Dikkatinizi toparlayabildiniz mi? Sesleri tahmin etmekte zorlandınız mı? ...

Sorulara verilen yanıtlar alındıktan sonra verilen sesleri kullanarak sınıfça sözel bir öykü oluşturmaları istenir. 


\section{ÖRNEK ETKINLIK - 3}

\section{Etkinliğin Adı: Her Deyimin Bir Öyküsü Var}

Etkinliğin Uygulanışı: Öğretmen, çantasından üç zarf çıkartır. Bu zarfların içinde Türkçenin zenginliğini gösteren söz grupları olduğu söyler. Öğrencilerden bu söz gruplarının türünü tahmin etmesi ister. Cevaplar alınır ve bunların birer deyim olduğu belirtilir. Öğrencilerden zarflardan birini seçmeleri ister. Her zarfın içinde bir deyim ve o deyimin öyküsü/ oyun metni yazıııdır. Öğretmen, deyimi çeken öğrencilerden o deyimin öyküsünde/ oyun metninde geçen kişi sayısınca bir grup oluşturmaları ve aralarında rol dağıtımı yapmaları ister. Gruplar oluşturulduktan sonra her gruba deyimde geçen kelimelerden yola çıkılarak bir ad verilir. Gruplara hazırlık için yeterli süre verilir. Canlandırma sırası kura ile belirlenir. Her grup sıra ile kendi deyiminin hikâyesini canlandııır. Öğrenciler, deyimlerin anlamları üzerine konuşturulur. Tip ve karakterleri canlandırırken ne hissettikleri sorulur. Kısa bir değerlendirme yapılarak çalışmaya son verilir.

\section{ÖRNEK ETKINLIK - 4}

\section{Etkinliğin Adı: Öykü Yazma Çalışmaları}

Etkinliğin Uygulanışı: Öğrencilere belirli sayıda cümle verilir. Öncelikle bu cümlelerin onlara ne ifade ettiği, ne çağrıştırdığı sorulur. Sonra bu cümleleri kullanarak öykü oluşturmaları ve oynamaları istenir.

- Nefes alın, nefes verin.

- $\quad$ Önemli bir şey var mı?

- 15 gün sonra tekrar gelin.

- $\quad$ Yemeklerden sonra.

- Ihlamur, nane, limon.

- $\quad$ Uykusuz kalmayın.

\section{ÖRNEK ETKINLIK - 5}

\section{Etkinliğin Adı: Sesimizi Tanıma ve Doğru Kullanma Çalışması}

Etkinliğin Uygulanışı: Öğrencilere kısa bir yazı verilir. Bu yazıyı nasıl okumalarına dair tonlama ile ilgili açıklayııı maddeler sunulur. Seçtikleri madde doğrultusunda metni okumaları istenir.

- Endişeli bir edayla.

- Kin dolu.

- Ümitsiz biri gibi.

- Şefkatle.

- Merhametle. 
- Günlerdir aç dolaşan biri gibi.

- Hasta biri gibi.

Kesin şu gürültüyü bakalım. Ben bu geceye yetişmek için nerden geliyorum biliyor musunuz? Üç gündür yoldayım, üstelik bugün motor da bozuldu tam dört saat denizin ortasında kaldık. Adaya çıktıktan sonra da beş dakika dinlenmeden giyindim, düğüne hazırlandım.

\section{ÖRNEK ETKINLIK - 6}

\section{Etkinliğin Adı: Bir Masalın Sonunu Değiştirme}

Etkinliğin Uygulanışı: Öğretmen tarafından okunan bilinen ya da çok iyi bilinmeyen bir masalın sonunun öğrencilerden kendi isteklerine göre tamamlamasını ve masalın yeni olan sonucunu canlandırmaları istenir.

\section{ÖRNEK ETKINLIK - 7}

\section{Etkinliğin Adı: Bireysel Doğaçlama Örnekleri}

Etkinliğin Uygulanışı: Öğrencilere bazı durumlar verilir ve öğrencilerden bu durumları hemen o anda oynamaları istenir.

- Öğretmenini dinliyorsun. Öğretmen yarın gireceğiniz çok önemli bir sınav için ipuçları veriyor. Ancak dün gece çok geç yatmışsın ve gözlerini açık tutmakta çok zorlanıyorsun.

- Nişanlın birkaç dakikaya kadar sana gelecek. Çevrene göz atıyorsun her şey çok iyi görünüyor. Mükemmel bir masa hazırlamışsın. Masada mumlar, çiçekler ve yemekler bir tablo kadar güzel. Güzel bir müzik odayı dolduruyor. Birdenbire nişan yüzüğünün parmağında olmadığını fark ediyorsun ve kapının zili çalınıyor.

- Arkadaşına çok kızgınsın çünkü doğum gününü kutlamadı. Seni unuttuğunu düşündükçe daha da sinirleniyorsun. Ona telefon etmeyi ve duygularını ona anlatmayı düşünüyorsun. Telefon hemen elinin altında.

- Çok sıkı bir zayıflama diyetindesin. Amacın bir haftada üç kilo vermek ama sen henüz bir kilo vermişsin. Buzdolabını açıyorsun ve annenin senede bir kez yaptığı nefis pastayı görüyorsun. Annenin pastasını asla görmezden gelemezsin.

\section{ÖRNEK ETKINLIK - 8}

\section{Etkinliğin Adı: İki Telefon}

Etkinliğin Uygulanışı: Öğrencilerden ismi, mesleği, yaşı, fiziksel özellikleri ve diğer tüm ayırt edici nitelikleriyle bir karakter oluşturmaları istenir. Karakterlerini oluşturan iki öğrencinin sandalyeye oturup yarattıkları karaktere sadık kalarak birbirleriyle telefon görüşmesi yapması istenir. Diğer 
öğrencilerden de konuşmayı dinlemeleri, karakterlerin ayırt edici özelliklerini ve hangi sebepten bu iki karakterin birbirleriyle konuştuklarını bulmaları istenir.

\section{ÖRNEK ETKINLIK - 9}

\section{Etkinliğin Adı: Çünkü Oyunu}

Etkinliğin Uygulanışı: Öğrencilerden daire biçiminde oturmaları istenir. Öğretmen oyunu başlatır ve bir olayı tanımlar. Sonra bir öğrenciden o olayın meydana gelmesini açıklayıcı bir neden söylemesi istenir. İkinci öğrenciden ise o olayın muhtemel bir sonucunu söylemeye çalışması istenir.

\section{ÖRNEK ETKINLIK - 10}

\section{Etkinliğin Adı: Duygu Çalışması}

Etkinliğin Uygulanışı: Aşağıdaki cümleyi karşısındaki duyguyu verecek şekilde tonlayınız:

$\begin{array}{lll}\text { - } & \text { Bıktım senden } & \text { (Utangaç biri gibi) } \\ \text { - } & \text { Bıktım senden } & \text { (Dedikoducu biri gibi ) } \\ \text { - } & \text { Bıktım senden } & \text { (Gülen biri gibi) } \\ \text { - } & \text { Bıktım senden } & \text { (Korkak biri gibi) } \\ \text { - } & \text { Bıktım senden } & \text { (Tehdit eden biri gibi) } \\ \text { - } & \text { Bıktım senden } & \text { (Kibar biri gibi ) } \\ \text { - } & \text { Bıktım senden } & \text { (Yalvaran biri gibi) }\end{array}$

\section{Sonuç}

Temel dil becerilerini geliştirmeye yönelik bütün drama oyunları, öğrencilere Türkçenin ifade imkânlarını sezdirme işlevi görür. Hedef, Türkçe konuşma ve yazmayı zevk haline getirmektir. Ana dili sevgisini bilince dönüştürmek bir sonraki aşamayı oluşturacaktır (Şimşek, 2007: 403). Türkçe derslerinde kullanılan klasik yöntemlerden kaçınılarak drama gibi duyuşsal yönden motive edici bir yöntemin kullanılması büyük fayda sağlayacaktır (Kara, 2007: 98).

Türkçe dersinde, ifade zorluğu çeken, yazamayan, dikkatli dinlemeyen, okuduklarını anlamayan ve anladıklarını aktaramayan çocukların bu sorunlarını ortadan kaldırabilmek için drama uygulamalarından faydalanılmalıdır. Dramanın kazandırdığı özgürlük hissi zamanla öğrenciyi yaratıcı düşünmeye ve yeni şeyler üretmeye yönlendirir. Öğrencilerin istekli olmaları, o işi yapabileceklerine inanmalarına bağlıdır. Sınıf içinde öğrencilere sunulan örnekler ve yapılan uygulamalar, seviyeye uygun olursa öğrenciler istekli duruma geleceklerdir (Doğan, 2009:189). 
Türkçe dersinde uygulanacak drama yöntemi sayesinde dersler daha zevkli; metinler daha eğlenceli; öğrenciler daha istekli ve girişken olacaktır. Drama sayesinde kendine güveni artan öğrenci, dikkatle dinler konuşma esnasında akıcı, düzgün cümleler kurar ve beden dilini kavrar. Kısaca anlama ve anlatma becerilerini başarılı ve etkili şekilde kullanma fırsatı bulur.

Öğrenci merkezli olan drama etkinlikleri sayesinde öğrenci dinlediğini anlama becerisini yaparak, yaşayarak kalıcı bir şekilde kazanmış olur. Soyut, karmaşık, farklı birçok konu, canlandırma yolu ile öğrencide somut bir hale getirilebilir.

Konuşma becerisinin ediniminde yapılan drama etkinlikleriyle özgüven sahibi olan; beden dilini rahatlıkla kullanabilen; belli bir topluluğa seslenebilen; fikirlerini akıcı bir şekilde dile getirebilen bireyler yetiştirebiliriz.

Dramayla öğrenciler okudukları metni daha iyi kavrar, karakterleri ve olayları özümser, metni canlandırarak metindeki olayları somutlaştırıp kendi yaşantıları haline getirirler.

Drama, yazma becerisini zevkli bir hale getirir. Sözcük, cümle oyunları, şiir ve diğer yazı türlerinin öğretilmesinde aktif bir yöntemdir.

Anlama ve anlatma becerileri olan dinleme, okuma, konuşma ve yazma becerilerinin birbirinden ayrılmaz bir bütün olarak ele alındığı Türkçe dersinde bu becerilerin öğrencilere kazandırılmasını sağlamak için dramadan yararlanılmalıdır. Ayrıca Üniversitelerde Türkçe Öğretmenliği bölümü öğrencilerine drama dersi verilmeli; mesleklerine başladıkları süreçte ise dramayla ilgili hizmet içi eğitimden geçirilmelilerdir. Öğretmenler, bu konuda aldıkları eğitimle daha bilinçli hareket edecek; derslerinde daha verimli olacaklardır.

\section{Kaynakça}

Aksan, D. (2007). Her yönüyle dil ana çizgileriyle dilbilim. Ankara: Türk Dili Kurumu Yayınları.

Arıkan, Y. (2007). Illköğretimler için uygulamalı tiyatro ve drama eğitimi. İstanbul: Pozitif Yayınları.

Aytaş, Gıyasettin (2008). Türkçe öğretiminde tematik yaratıcı drama etkinlik ve uygulamaları. Ankara: Akçağ Yayıncilık.

Baş, H.Z. (2002). Drama yöntemiyle Türkçe eğitimi. Ankara: Uzerler Matbaacılık.

Banguoğlu, T. ( 1990). Türkçenin grameri. Ankara: Türk Dil Kurumu Yayınları.

Demirel, Ö. (2002). Türkçe ve sınıf öğretmenleri için Türkçe öğretimi. Ankara: Pegem A Yayıncılık.

Dirim, A. (1998). Okul öncesi eğitiminde yaratıcı drama. İstanbul: Esin Yayınevi.

Doğan, Y. (2009). Konuşma becerisinin geliştirilmesine yönelik etkinlik önerileri. Türk Eğitim Bilimleri Dergisi. $7(1), 185-204$.

Kara, Ö.T. (2007). Drama yönteminin ilköğretim Türkçe derslerinde kullanılması (Poster Bildiri). Türkiye 9. Drama Liderleri Buluşması ve Ulusal Drama Semineri, (22-24 Haziran 2007, Bolu), Drama Kavramları Bildiri Kitabı, Ankara: Oluşum Yayınları, s.97-98.

Karadağ, E. ve Çalışkan, N. (2005). Kuramdan uygulamaya ilköğretimde drama 'oyun ve işleniş̧ örnekleriyle'. Ankara: Anı Yayıncilı.

Şimşek, T. (2007). Drama İçinde: H. Akyol ve A. Kırkkılıç (Ed.), Illköğretimde Türkçe öğretimi. Ankara: Pegem A Yayıncilı. 


\section{Türkçe Öğretiminde Drama}

Köklü, S. (2003). Türkşe öğretiminde 7. ve 8. sınıf öğrencilerine dinlediğini anlama davranışııın kazandırılmasına dramatizasyonun etkisi. Yayımlanmamış Yüksek Lisans Tezi, Marmara Üniversitesi, Eğitim Bilimleri Enstitüsü, İstanbul.

Milli Eğitim Bakanlığı. (2006). ilköğretim Türkçe dersi öğretim programı ve kılavuzu (6, 7 ve 8. sınıflar) Ankara: MEB

Milli Eğitim Bakanlığı. (2005). Illköğretim Türkçe dersi öğretim programı ve kılavuzu (1-5. sınıflar). Ankara: MEB Önder, A. (2007). Yaşayarak öğrenme için eğitici drama kuramsal temellerle uygulama teknikleri ve örnekleri. istanbul: Epsilon Yayıncılık.

Özbay, M. (2006a). Türkçe özel öğretim yöntemleri-I. Ankara: Öncü Kitap.

Özbay, M. (2006b). Türkçe özel öğretim yöntemleri-ll. Ankara: Öncü Kitap.

Rooyackers, P. (2009). ilköğretim derslerinde 101 drama oyunu. İstanbul: Esin Yayınevi.

San, i. (1990). Eğitimde yaratıcı drama. Ankara Üniversitesi Eğitim Bilimleri Fakültesi Dergisi, 23 (2), 573-582.

Türk Dil Kurumu. (2005). Türkçe Sözlük. Ankara: TDK Yayınları.

Ünalan, Ş. (2006). Türkçe öğretimi. Ankara: Nobel Yayın Dağıtım.

Ünsal, B. (2005). İlköğretim ikinci kademe (6, 7, 8. sınıflar) Türkçe dersinde drama yönteminin çocukların dil ve anlatım becerilerine katkısı. Yayımlanmamış Yüksek Lisans Tezi, Gazi Üniversitesi, Eğitim Bilimleri Enstitüsü, Ankara.

Üstündağ, Tülay (2009) “Yaratıcı Drama Öğretmenin Günlüğü ”Ankara: Pegem A Akademi.

Yalçın, A. (2002). Türkçe öğretim yöntemleri yeni yaklaşımlar. Ankara: Akçağ Yayınları.

Yılmaz, T.T. (1999). Türkçe öğretiminde yaratııı drama yöntemiyle diksiyon becerileri kazandırmaya ilişkin bir model önerisi yaklaşımı. Yayımlanmamış Yüksek Lisan Tezi, Ankara Üniversitesi, Sosyal Bilimler Enstitüsü, Ankara. 